\title{
FRET-assisted photoactivation of flavoproteins for in vivo two-photon optogenetics(Abstract_要旨)
}

\section{$\operatorname{AUTHOR}(S):$}

Kinjo, Tomoaki

\section{CITATION:}

Kinjo, Tomoaki. FRET-assisted photoactivation of flavo proteins for in vivo two-photon optogenetics. 京都大学, 2020, 博士(医学)

ISSUE DATE:

2020-03-23

URL:

https://doi.org/10.14989/doctor.k22301

RIGHT: 


\begin{tabular}{|l|c|c|c|}
\hline 京都大学 & \multicolumn{1}{|c|}{ 博士 (医学) } & 氏名 & \multicolumn{1}{|c|}{ 金 城 智 章 } \\
\hline 論文題目 & $\begin{array}{l}\text { FRET-assisted photoactivation of flavoproteins for in vivo two-photon } \\
\text { optogenetics } \\
\text { (生体内での二光子励起光遺伝学操作法を目的とする フェルスター共鳴 } \\
\text { エネルギー移動に基づくフラホホタンハク質光活性化技術の開発) }\end{array}$ \\
\hline
\end{tabular}

(論文内容の要旨)

\section{【背景と目的】}

近年、フェルスター共鳴エネルギー移動 (FRET) を利用したバイオセンサーによ り、生体内のシグナル伝達を、高い時空間解像度で観察することが可能になってき た。しかし、観察したシグナルと、結果としておこる表現型との因果関係の証明は観 察のみでは困難であった。この問題の解決策として、シグナル伝達経路を光で操作可 能な光誘導性二量体化システムが報告されている。しかし、本システムは培養細胞で はよく使用されているが、生体での使用例はほとんどない。そのため、生体内で使用 可能な光遺伝学ツールの開発を目的として、本研究を行った。

\section{【二光子励起用光遺伝学ツールの開発】}

青色光誘導性二量体化システムである、Cryptochrome 2 (CRY2)-cryptochromeinteracting basic-helix-loop-helix (CIB)を用いて、二光子励起法によるシグナル伝達の活性 化を試みたが、CRY2 は二光子励起効率が低く、生体内での使用に耐えないことが判明 した。その原因として、CRY2 の二光子吸収効率が低いことが考えられた。

CRY2 の発色団である flavin adenine dinucleotide (FAD)および青色蛍光タンパク質 mTagBFP2 のモル吸光係数から、FAD の二光子吸収は mTagBFP2 の 16 分の 1 程度と推 定されたこれれより、二光子励起効率の高い mTagBFP2 から FAD への FRET を利用 することで、CRY2 を二光子励起で活性化できる可能性が示唆された。

mTagBFP2-CRY2 間での FRET の有無を検証するため、蛍光寿命イメージング曊微 鏡法によるスクリーニングを行った。結果、mTagBFP2-CRY2 融合タンパク質において mTagBFP2 蛍光寿命の短縮を認め、mTagBFP2 から CRY2 へ FRET が起こることが確認 された。本技術を FRET-assisted photoactivation (FRAPA) と命名した。更に、構造モデル に基づき、mTagBFP2 を CRY2 内部に挿入して発色団間の距離を最適化することで、 二光子励起効率の高い two-photon activatable CRY2 (2paCRY2)を開発した。

また、FRAPA の汎用性を検証するため、CRY2 と同様のフラボタンパク質由来光 遺伝学ツールである Light-Oxygen-Voltage (LOV)ドメインについても検証を行い LOV が、シアン蛍光タンパク質 mTFP1 からの FRETにより活性化できることを示した。

\section{二光子励起光遺伝学操作法を用いた ERK シグナル伝播様式の検証】}

本技術の有用性を示寸ため、2paCRY2 システムを用いて、細胞の増殖やがん化に 重要な経路として RAF/ERK 経路を活性化可能な、2paRAF システムを開発した。ま た、2paRAF を発現するイヌ腎臟尿細管上皮細胞株を用いて、マトリゲル上で三次元の 管腔構造体を作成し、三次元構造内の単一細胞で ERK 活性を制御できること示した。 同様に、2paRAF を発現する遺伝子改変マウスの皮膚基底層で単一細胞の ERK 活性を 制御できることを示した。更に、皮膚増殖促進時においては、ERK 活性伝搬距離が延 長することを見出した。
【結論】

蛍光タンパク質からの FRET を利用して、生体内で使用可能な二光子励起効率の高 い光遺伝学ツールを開発した。また同ツールを用いて、三次元の管腔構造体、腸オル ガノイド、生体マウス皮膚基底層において ERK 活性を単一細胞レベルで操作可能であ ることを示した。

\section{(論文審査の結果の要旨)}

光遺伝学操作法の発展により、細胞内シグナル伝達経路の光操作が可能になってき た。しかし、生体深部組織や三次元空間の目的の細胞においてシグナル伝達を操作す ることは依然として困難であった。申請者は、青色光誘導性二量体化システム CRY2 を用いて二光子励起法によるシグナル伝達操作を試みたが、CRY2 をはじめとするフラ ボタンパク質は二光子吸収効率が低く、生体内での使用が困難であった。この問題を 克服するために、申請者は蛍光タンパク質からの FRET により光遺伝学ツールを活性 化させる、FRET-assisted photoactivation (FRAPA)法を開発した。この技術により、従来 は困難であった二光子励起法による CRY2 の活性化が可能となり、細胞由来の三次元 構造体や生体皮膚組織において、単一細胞の解像度で ERK 活性を制御できることを示 した。また、皮膚基底層における ERK 活性伝播は、正常皮膚においては抑制されてお り、TPA 刺激時に限定して起きることが示唆された。更に、CRY2 以外のフラボタンパ ク質への展開の可能性を検討し、LOV2 についても FRAPA 法が適用可能であることを 示した。

以上の研究は、二光子励起光遺伝学操作法の技術開発および生体皮膚組織における ERK 活性伝播の機能解明に貢献し、生体内における細胞内シグナル伝達の光操作技術 の開発ならびに細胞間伝播機構の解明に寄与寸るところが多い。

したがって、本論文は博士 (医学) の学位論文として価值あるものと認める。

なお、本学位授与申請者は、令和 1 年 10 月 15 日実施の論文内容とそれに関連した 試問を受け、合格と認められたものである。 